\title{
Haplotype analysis at the alcohol dehydrogenase gene region in New Zealand Māori
}

\author{
David A. Hall · Geoffrey K. Chambers • \\ Rodney A. Lea
}

Received: 19 September 2006/ Accepted: 12 November 2006/Published online: 19 December 2006

(C) The Japan Society of Human Genetics and Springer 2006

\begin{abstract}
Alcohol response is a genetically influenced trait, and there is significant variation in the patterns of alcohol consumption between Māori and Caucasians in New Zealand. Previous studies have found that a variant of the alcohol dehydrogenase $(\mathrm{ADH})$ gene $(\mathrm{ADH} 1 \mathrm{~B} * 47 \mathrm{His})$ is associated with protection against alcohol dependence in Māori. Here we extend our investigation of the $\mathrm{ADH}$ genes, hypothesising a different haplotype signature in Maori compared to Caucasians. We analysed nine single nucleotide polymorphisms (SNPs) spanning a $500-\mathrm{kb}$ region on chromosome $4 \mathrm{q}$ surrounding the ADH1B variant and several other alcohol-metabolising genes (ADH 4, 5, 6, 7). Genotyping was carried out on 47 unrelated Māori individuals, and allele frequencies were compared to the Caucasian population. Large differences in minor allele frequencies were observed between Māori and Caucasian populations for six SNPs $(P<0.01)$. There was also strong linkage disequilibrium (LD) observed among SNP alleles in Maori indicating the presence of extended ancestral haplotype blocks $(P<0.01)$. Our results suggest that the Māori population has a different haplotype signature at the $\mathrm{ADH}$ gene region compared to Caucasians. These findings probably reflect the unique gene
\end{abstract}

D. A. Hall · G. K. Chambers

Victoria University of Wellington,

P.O. Box 600, Wellington, New Zealand

D. A. Hall · R. A. Lea $(\bowtie)$

Institute of Environmental Science and Research Limited,

Kenepuru Science Centre, 34 Kenepuru Drive,

P.O. Box 50-348, Porirua,

Wellington, New Zealand

e-mail: rod.lea@esr.cri.nz flow history of this genomic region in Maori and should be beneficial for designing future genetic association studies of alcohol-response traits and associated disorders in Polynesians.

Keywords Alcohol dehydrogenase - Maori ·

New Zealand · Linkage disequilibrium · Polymorphism

$\begin{array}{ll}\text { Abbreviations } \\ \text { NZ } & \text { New Zealand } \\ \text { ADH } & \text { Alcohol dehydrogenase } \\ \text { SNP } & \text { Single nucleotide polymorphism } \\ \text { LD } & \text { Linkage disequilibrium } \\ \text { MAF } & \text { Minor allele frequency }\end{array}$

\section{Introduction}

The Māori population of New Zealand (NZ) represents the final link in a long chain of island-hopping voyages beginning in Taiwan and stretching across the South Pacific-the last of the great human migrations. There is evidence that this population originated from restricted groups of common ancestors around 800 years ago and underwent rapid growth within the geographic isolation of NZ (Marshall et al. 2005). Considering this unusual history we envisage that the Māori population will have formed distinctive genomic signatures, with haplotype blocks likely to extend over larger distances and allele frequencies likely to differ markedly from those of other human populations. It is plausible that genomic variation peculiar to Māori may partially explain differences in disease 
susceptibility in this indigenous population compared to Caucasians.

Variation in ADH enzyme activity influences metabolic response to ingested alcohol and susceptibility to abuse behaviour. This variation is due in part to single nucleotide polymorphisms (SNPs) within the genes that encode the alcohol dehydrogenase (ADH) enzymes (Thomasson et al. 1993). One commonly studied exonic SNP allele in ADH1B (variously referred to as $\operatorname{Arg} 47 \mathrm{His}, \mathrm{ADH} 1 \mathrm{~B} * 2$, or $\mathrm{ADH} 2 * 2$, but now called $\mathrm{ADH} 1 \mathrm{~B} * 47 \mathrm{His})$ has been associated with protection against alcohol dependence in numerous studies (Chambers et al. 2002a; Chen et al. 1997; Osier et al. 2002), and is common in Asian and Pacific populations (Chambers et al. 2002a; Chen et al. 1997). Previously, Chambers et al. (2002b) compared ADH genotype frequencies between alcoholics and nonalcoholics in a sample of young male native NZ Polynesians (Māori). They found that the AD$\mathrm{H} 1 \mathrm{~B} * 47 \mathrm{His}$ frequency in diagnosed Māori alcoholic patients (0.15) was much lower than that in Māori non-alcoholic volunteer controls $(0.42, P<0.01)$, suggestive of a protective effect. Studies have also implicated other $\mathrm{ADH}$ gene variants in alcoholism traits and shown highly variable patterns of linkage disequilibrium (LD) across this genomic region among different ethnic populations (Osier et al. 2002; Edenberg et al. 2006).

Here we examine SNPs, and estimate LD, across the ADH region in a sample of Māori in an attempt to characterise the patterns shaped by migrations and that may have relevance to future genetic studies of alcohol response in people with Polynesian ancestry. We concentrate on comparisons between Māori and Caucasian populations because of the hypothesis that the differences in alcohol consumption patterns between these two major NZ ethnic groups may be partially due to genetic differences at the $\mathrm{ADH}$ loci.

\section{Methods}

\section{Study population}

We analysed a sample of 47 unrelated male and female individuals drawn from the general population of Wellington, NZ. The subjects reported having eight Māori great grandparents and as such might be representative of the ancestral Māori population (i.e. they have very little Caucasian admixture). All individuals provided informed consent prior to enrolling in the study. Approval for this phase of our research programme was granted by the Central Region Ethics Committee (New Zealand) in 2004.

\section{SNP information}

The nine SNPs were chosen to span the entire set of $\mathrm{ADH}$ genes on chromosome 4, and include both intronic and exonic polymorphisms. SNPs were chosen based on existing knowledge of mutations that were well characterised in the literature. No SNPs were chosen within the ADH1A gene because, at the time of SNP selection, we were not aware of any significant mutations within that gene. Genotyping was done via a service contract with the Australian Genome Research Facility (http://www.agrf.org.au), which uses the Sequenom MassArray Genotyping System (Buetow et al. 2001). Figure 1 provides a visual overview of the ADH gene region, together with an indication of the relative positions of the nine SNPs.

Statistical analyses

Allele frequencies at SNP sites were calculated for the Māori sample and compared with Caucasian frequencies derived from the ALFRED (Rajeevan et al. 2003) and HapMap (The International HapMap Consortium 2005) databases. $\chi^{2}$ values $(1 \mathrm{df})$ were calculated and their associated probabilities determined using the CHIDIST function in OpenOffice.org Calc (OpenOffice.org 2006). The GOLD program was used to identify LD (haplotype) patterns among SNPs within the Māori sample.

\section{Results and discussion}

SNP allele frequencies

Table 1 shows a comparison of the minor allele frequencies (MAFs) in the Māori and Caucasian samples. One SNP, rs1789882, was excluded due to the observed allele frequencies deviating from Hardy-Weinberg Equilibrium (HWE, $P<0.01$ ). We suspect that the deviation is due to a failure in the genotyping assay, and has no biological significance. Allele frequency differences between these two populations were statistically significant for all remaining SNPs except for rs4699733 and rs971074.

The largest observed difference in allele frequency was at the key SNP rs1229984 (ADH1B*47His), as reported previously by Chambers et al. (2002b). The 
Fig. 1 An overview of a region of human chromosome 4 , showing the relative positioning of the alcohol dehydrogenase $(A D H)$ genes and single nucleotide polymorphisms (SNPS). The minor allele of the rs1229984 SNP (boxed) is the frequently studied mutation $\mathrm{ADH} 1 \mathrm{~B} * 47 \mathrm{His}$

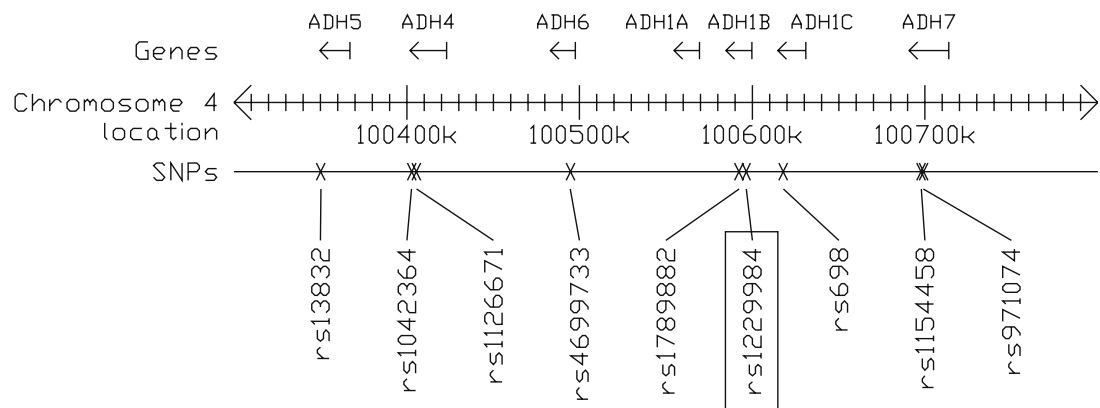

Table 1 Minor allele frequency (MAF) statistics for single nucleotide polymorphisms (SNPs) spanning the alcohol dehydrogenase $(\mathrm{ADH})$ region on chromosome 4

\begin{tabular}{|c|c|c|c|c|c|c|c|c|}
\hline RefSNP ID & $\begin{array}{l}\text { Location } \\
(\mathrm{kb})\end{array}$ & $\begin{array}{l}\text { Gene } \\
\text { region }\end{array}$ & SNP & $\begin{array}{l}\text { Coding change } \\
\text { (if any) }\end{array}$ & $\begin{array}{l}\text { Māori MAF } \\
(2 \mathrm{~N})^{\mathrm{a}}\end{array}$ & $\begin{array}{l}\text { Caucasian } \\
\text { frequency }(2 \mathrm{~N})^{\mathrm{b}}\end{array}$ & Difference & Probability $^{\mathrm{c}}$ \\
\hline rs13832 & 100350 & ADH5 & $\mathrm{T} \rightarrow \mathrm{G}$ & - & $0.10(90)$ & $0.38(164)$ & 0.28 & $<0.01$ \\
\hline rs1042364 & 100403 & $\mathrm{ADH} 4$ & $\mathrm{G} \rightarrow \mathrm{A}$ & $\mathrm{G} \rightarrow \mathrm{R}$ & $0.05(94)$ & $0.32(164)$ & 0.28 & $<0.01$ \\
\hline rs1126671 & 100406 & ADH4 & $\mathrm{G} \rightarrow \mathrm{A}$ & $\mathrm{V} \rightarrow \mathrm{I}$ & 0.07 (94) & $0.33(164)$ & 0.26 & $<0.01$ \\
\hline rs4699733 & 100495 & ADH6 & $\mathrm{C} \rightarrow \mathrm{G}$ & - & $0.31(94)$ & $0.23(164)$ & 0.08 & 0.18 \\
\hline rs1789882 ${ }^{\mathrm{d}}$ & 100592 & ADH1B & $\mathrm{A} \rightarrow \mathrm{G}$ & Synonymous & $0.45(94)$ & 0.88 (164) & 0.43 & $<0.01$ \\
\hline rs1229984 & 100596 & ADH1B & $\mathrm{G} \rightarrow \mathrm{A}$ & $\mathrm{R} \rightarrow \mathrm{H}$ & $0.45(94)$ & $0.04(328)$ & 0.41 & $<0.01$ \\
\hline rs698 & 100618 & ADH1C & $\mathrm{A} \rightarrow \mathrm{G}$ & $\mathrm{I} \rightarrow \mathrm{V}$ & $0.30(94)$ & $0.44(358)$ & 0.14 & $<0.01$ \\
\hline rs1154458 & 100698 & ADH7 & $\mathrm{C} \rightarrow \mathrm{G}$ & - & 0.19 (94) & $0.38(394)$ & 0.19 & $<0.01$ \\
\hline rs971074 & 100699 & ADH7 & $\mathrm{G} \rightarrow \mathrm{A}$ & Synonymous & $0.04(92)$ & $0.12(410)$ & 0.08 & 0.56 \\
\hline
\end{tabular}

a $2 \mathrm{~N}$ indicates the total number of alleles in the population data set for that allele

b The allele frequency reported here for the Caucasian population is a combination of data from the HapMap project (rsl3832rs4699733), as well as the ALFRED database (rsl229984-rs971074)

c Probabilities are based on $\chi^{2}$ tests with one degree of freedom

d This SNP was subsequently removed from the analysis because the observed allele frequencies deviated significantly from HWE expectation

minor allele was present at a frequency of 0.41 in the Māori population but was only observed at a frequency of 0.04 in the Caucasian population.

Figure 2 shows LD (haplotype) analysis results for ADH SNPs in the Māori sample. The figure indicates a region of relatively high LD between SNPs rs4699733 and rs971074. In this region there were two SNPs that were in complete LD $\left(\mathrm{D}^{\prime}=1, P<0.01\right)$ with each other (rs1229984/rs698).

The haplotype frequencies for this major LD block spanning SNP rs1229984 and rs698 (Fig. 2) were markedly different between Māori and Caucasian populations $(P<0.05)$. Haplotype AA had a much lower frequency in the Caucasian population (0.02) compared to Māori (0.45). The GA and GG haplotypes had lower frequencies in the Māori (0.26 and 0.30 respectively) compared to Caucasian ( 0.54 and 0.44 respectively). The AG haplotype was not observed.

In this study we observed marked differences in the allele frequency between Māori and Caucasian groups at six SNPs spanning the ADH gene region. In Māori, a region of apparent high LD including the well-known

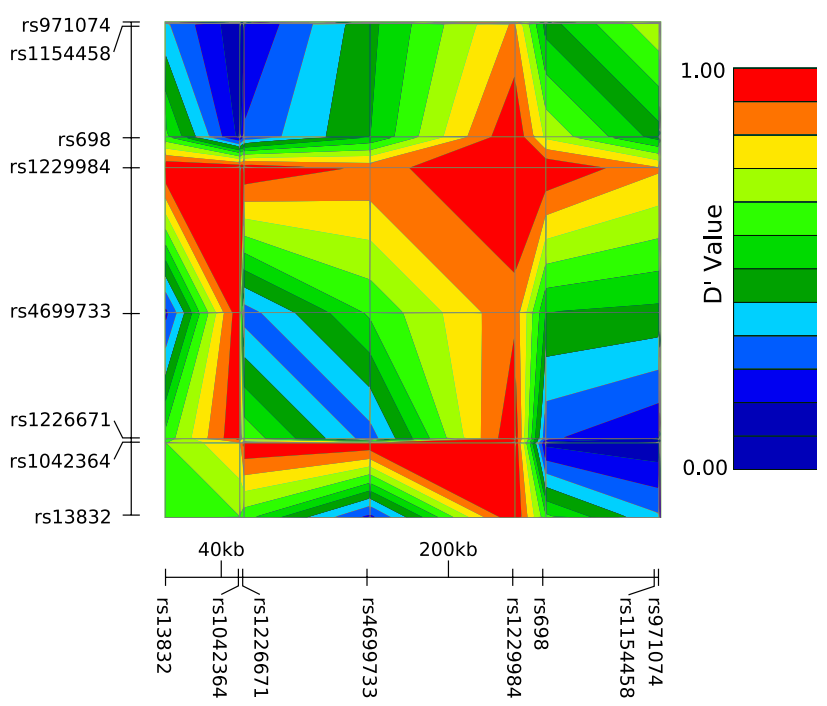

Fig. 2 LD patterns of SNPs spanning the ADH gene region in Maori. D' values $>0.50$ are statistically significant at $\alpha=0.05$

ADH1B variant was identified, which is perhaps indicative of a large $(\approx 200 \mathrm{~kb})$ haplotype block of Polynesian origin. 
In conclusion, we have identified very different haplotype signatures at the alcohol-metabolising genes in Māori compared to Caucasians. These findings probably reflect the unique genetic history of this population and provide important information for designing association (including admixture mapping) studies of the ADH genomic region in alcohol-related traits in Polynesians.

Acknowledgements This project was supported by funds from the New Zealand Alcohol Advisory Council, Wellington Medical Research Foundation and Environmental Science and Research Ltd.

\section{References}

Buetow KH, Edmonson M, MacDonald R, Clifford R, Yip P, Kelley J, Little DP, Strausberg R, Koester H, Cantor CR, Braun A (2001) High-throughput development and characterization of a genomewide collection of gene-based single nucleotide polymorphism markers by chip-based matrixassisted laser desorption/ionization time-of-flight mass spectrometry. Proc Natl Acad Sci USA 98:581-584

Chambers GK, Day DJ, Marshall SJ, Robinson GM (2002a) Alcohol dependence: advances in understanding, diagnosis and treatment. N Z Sci Rev 59:35-41

Chambers GK, Marshall SJ, Robinson GM, Maguire S, NewtonHowes J, Chong NL (2002b) The genetics of alcoholism in Polynesians: alcohol and aldehyde dehydrogenase genotypes in young men. Alcohol Clin Exp Res 26:949-955
Chen WJ, Loh EW, Hsu YPP, Cheng ATA (1997) Alcohol dehydrogenase and aldehyde dehydrogenase genotypes and alcoholism among Taiwanese aborigines. Biol Psychiatry 41:703-709

Edenberg HJ, Xuei X, Chen HJ, Tian H, Wetherill LF, Dick DM, Almasy L, Bierut L, Bucholz KK, Goate A, Hesselbrock V, Kuperman S, Nurnberger J, Porjesz B, Rice J, Schuckit M, Tischfield J, Begleiter H, Foroud T (2006) Association of alcohol dehydrogenase genes with alcohol dependence: a comprehensive analysis. Hum Mol Genet 15:1539-1549

The International HapMap Consortium (2005) A haplotype map of the human genome. Nature 437:1299-1320

Marshall SJ, Whyte ALH, Hamilton JF, Chambers GK (2005) Austronesian prehistory and polynesian genetics: a molecular view of human migration across the Pacific. N Z Sci Rev 62:75-80

OpenOffice.org (2006) [Computer program] Version 2.0.3. OpenOffice.org: free office suite. http://www.openoffice.org/

Osier MV, Pakstis AJ, Soodyall H, Comas D, Goldman D, Odunsi A, Okonofua F, Parnas J, Schulz LO, Bertranpetit J, Bonne-Tamir B, Lu RB, Kidd JR, Kidd KK (2002) A global perspective on genetic variation at the $\mathrm{ADH}$ genes reveals unusual pattern of linkage disequilibrium and diversity. Am J Hum Genet 71:84-99

Rajeevan H, Osier MV, Cheung KH, Deng H, Druskin L, Heinzen R, Kidd JR, Stein S, Pakstis AJ, Tosches NP, Yeh CC, Miller PL, Kidd KK (2003) Alfred-the allele frequency database-update. Nucleic Acids Res 31:270-271

Thomasson HR, Crabb DW, Edenberg HJ, Li T-K (1993) Alcohol and aldehyde dehydrogenase polymorphisms and alcoholism. Behav Genet 23:131-136 